sign that the establishments have been endowed with resources which might have been better spent in universities.

\section{WHIMPER, NO BANG}

The dispute between the British universities and the Government about the proposal that students from overseas should pay higher fees has ended in an anticlimax. The statement by the vice-chancellors (see page 1059) bristles with discontent, but Mr. Crosland will have his way, and fees will be increased in the autumn by a factor of roughly three. The fact that the Government has agreed to set up a hardship fund for students who will be badly hit by the new regulations will repair some of the damage, although it would obviously have been better for the reputation of the Government if this proposal had not been wrung from it by a storm of protest. There remain two separate kinds of issues to be resolved.

The level of fees which the universities should charge is in itself an important issue. The protest about the raising of fees for students from overseas has been levelled at the discriminatory character of this proposal, and there is good reason to fear some of its repercussions. But there is a good case for a general increase in the tuition fees for all students at British universities. The Robbins Commission was only voicing a view that is widely held when it recommended a general increase, largely on the grounds that the universities would then be less directly dependent on a single source of funds-the University Grants Committee. A more realistic scale of charges would also help to remind the universities of the real costs of their operations, and might therefore be a spur to a greater concern for efficiency. If the Government is now prepared to have serious discussions on these problems, the vice-chancellors will have something to be pleased about. They would, however, be mistaken if they thought that they could establish a higher scale of fees without making a spontaneous and convincing demonstration that they are prepared to operate in a thoroughly modern way. In the long run, they will also have to reconcile themselves to a much greater variation from one university to another.

The dispute about overseas fees has also questioned in an acutely disturbing way the character of the relationship between the universities, the University Grants Committee and the Government. Theoretically, the universities are autonomous, and are protected by the UGC from direct interference by the Government. On this occasion, it now seems plain, the UGC was not consulted about the specific proposal that fees for overseas students should be increased, while the universities as a whole have had to act as the Government decreed. To be sure, some universities agreed with the Government's proposal, and others had no stomach for a fight, but even so, this sequence of events lends support to those who think that the UGC is no longer an effective buffer. Changing circumstances, and particularly the growing scale of public support for the universities, have made it inevitable that there should be important changes in the past two decades. Unfortunately the universities have been slow to recognize what has been going on. The result is that they have no collective means of resisting pressure from outside-or of applying it when necessary. In the discussions which lie ahead, the Committee of Vice-Chancellors must work not merely for more realistic fees but for recognition as the proper negotiating body on all matters of this kind.

\section{STARTING FROM SCRATCH}

The Natural Environment Research Council has produced its first report (see page 1059), and this is something to be grateful for even if it is later than it should have been. Now it should at least be possible to make more reasonably informed guesses about the way in which the new council will tackle the exceedingly difficult job of supporting research in a field which is necessarily ill-defined, and which is almost certain to remain like that. To judge from what the first report has to say, planning has been conditioned by the character of the laboratories which have fallen into the council's hands-the Institute of Oceanography, the various institutes concerned with the geological sciences and now tidily grouped together, and a number of marine biology laboratories, for example. The Nature Conservancy is also an inner force to be reckoned with, especially in its occasional role as the professional counterpart of the Council for the Preservation of Rural England. Nobody will be surprised that oceanography and marine biology get the fullest treat. ment in the report.

If, however, the immediate future is filled with sensible projects, the more distant future is probably as much of a puzzle for the research council as for those who may work with it. The council seems to have pinned its faith in a utilitarian concept of its influence. In places the first report reads like a précis of some of the things said in the name of the Inter. national Biological Programme. There is talk of making the Atlantic more productive of fish, and of the way in which a better understanding of wave motion may in the long run help both with the design of ships and the disposal of coastal effluents. But can the council hope to hold to this line without also undertaking the technology of exploitation? Will it be found drilling in the North Sea one day? And what will be its relations with the universities? These are some of the questions which the committee of the National Academy of Sciences on oceanography has been trying to answer (see Nature, 213, 937; 1967). It is to be hoped that by a year from now, the Natural Environment Research Council will have answers of its own. 